\title{
POSITION
}

\section{HINKELINKE OG HALTEFANDEN}

\author{
EU for antropologer
}

Jeg har netop regnet ud, at jeg har haft stemmeret i 28 år. Anledningen til, at jeg har givet mig til at regne på det, er at det forekommer mig, at jeg har hørt om og skullet stemme om „EU, for eller imod“ så længe jeg har levet. Det er ikke helt løgn: Danmark har været medlem af EU (EF) i 25 af de 28 år. Hele mit voksne liv er gået med at debattere fordele og ulemper ved sammenslutningen af de europæiske stater, og nu hænger det mig en kilometer ud af halsen. Jeg kan slet ikke bære tanken om at skulle til det endnu engang, ved middagsborde, redaktionsmøder, i bussen, i avisen, i fjernsynet, på gaden og hos fris $\emptyset$ ren. Jeg holder det ikke ud. Jeg vil snakke om noget andet. Om andre politiske problemer, for eksempel. De kan snart for min skyld melde landet ud af hvad som helst, bare jeg kan blive fri for at høre om det. Så kunne resten af Europa også komme videre med arbejdet.

Men før jeg lukker og slukker for interessen, kunne jeg tænke mig at lave en lille analyse af, hvad der er på spil i denne debat - og hvad der altså keder mig til kvalmegrænsen. Det kunne jo tænkes, at det havde noget med debatten at gøre - og ikke bare med min manglende tålsomhed. Der er strengt taget andre debatter, som står på $\mathrm{i}$ århundreder, uden at man af den grund skriger. Den om forholdet mellem individ og samfund, for eksempel. Eller den om forholdet mellem arv og miljø. Eller den om den fri vilje versus prædestination via skæbnen, kulturen, hormonerne eller generne. Disse debatter adskiller sig fra EU-debatten på flere forskellige måder, men én af de væsentligste er formentlig, at man ikke sender spørgsmålene til folkeafstemning. Det er meget sjovere at diskutere spørgsmål, som ikke skal munde ud i en dikotomi. Hvad kan dét nu skyldes?

Mange forestiller sig ellers, at dikotomier eller dualismer er det, der făr verden til at gå rundt. To køn, liv og død, lys og mørke, varme og kulde, oppe og nede, ude eller inde, her eller ikke-her, ja eller nej. Den, der ikke er for mig, er imod mig, det siger Herren selv, og en sag kan altid ses fra to sider. Lige nøjagtigt to.

Hvad skulle da være mere passende end at ordne det politiske univers i for eller imod? Det skal jeg sige Dem: Det er kedeligt. Og det er også helt, helt forkert.

Lad os se på argumenterne i EU-debatten. De er i saglig henseende af to typer: det $\emptyset$ konomiske og det sikkerhedspolitiske. Inden for den $\emptyset$ konomiske argumenttype finder man en grundlæggende enighed om, at indkomster skaffes på et transnationalt marked. Uenighederne går dels på, hvordan man scorer mest mulig kasse, og dels på, hvad man gør med overskuddet. Vil det være mere indbringende at være med i den fælles mønt og 
have uhindret adgang til det store fællesmarked? Eller er den uhindrede adgang uafhængig af, om pengene hedder det samme; er der eventuelt tale om, at hindringer på de europæiske markeder slet ikke er af økonomisk art, men snarere kulturelle eller sproglige eller sådan noget? Og hvad med overskuddet? Er det umagen værd at blive rig af et medlemsskab, hvis man alligevel skal aflevere pengene igen, så polakker og portugisere kan få nye badeværelser og charterferier? Kan man være overbevist om, at de fælles kasser vil blive bestyret, så danskere kan få socialhjælp og gratis universitetsundervisning? Er det ikke sikrere at bestyre overskuddet fra Christiansborg?

Allerede inden for det $\emptyset$ konomiske felt ser vi altså fire mulige standpunkter: ja til EUmarked, nej til EU-finanspolitik; ja til EU-marked, ja til EU-finanspolitik; nej til EUmarked, nej til EU-finanspolitik og nej til EU-marked, ja til EU-finanspolitik. De kan ordnes i en net lille hinkerude.

Hvis vi går videre til sikkerhedspolitikken, viser det sig, at det dér forholder sig ligesådan. De overordnede uenigheder angår militært samarbejde og fælles udenrigspolitik, og de kan grupperes i fire tilsvarende felter. Ja til WEU (militært samarbejde), nej til et EU-udenrigsministerium; nej til begge dele (det er den øjeblikkelige Edinburgh-orden); nej til WEU, ja til fælles udenrigspolitik og endelig ja til både WEU og et EU-udenrigsministerium. Igen en net lille hinkerude, men desværre falder hinkeruderne ikke sammen. Man kan sagtens være tilhænger af både EU-marked og finanspolitik men samtidig helt imod både WEU og det udenrigsministerielle samarbejde. Og man kan mageligt være tilhænger af sikkerhedspolitisk samarbejde med det helt store udtræk og samtidig rasende modstander af fælles finanspolitik.

Og det allerværste er, at alle disse mange standpunkter hver især kunne føres ud i livet som politisk virkelighed. Ingen af dem er urealistiske. Edinburgh-aftalen var et fors $ø g$ på at lave en særlig ordning af denne type på sidelinien for Danmark, eftersom halvanden million danske nej-sigere ikke kunne regne med at overbevise Europas andre hundreder af millioner mennesker om, at andre kombinationer end Maastricht-traktatens var sagen.

Pointen er nemlig, at kombinatorikkerne er det, der forhandles om, når stats- og regeringscheferne og deres håndgangne mænd $\mathrm{m} / \mathrm{k}$ står ud af limousinerne med deres mapper for at mødes til disse uendelige sessioner og prøve at udstikke den fremtidige udvikling. Så når traktaterne kommer til ratifikation i de nationale parlamenter, er der sådan set ikke mere at kombinere. Før næste gang.

Men alligevel stemmer vi altså i Danmark om hver eneste traktatændring, og forud for afstemningen debatterer vi. Hvordan går dét så for sig? Der er jo ikke længere mulighed for at stemme om en anden kombination af elementerne end den, vore ministre er blevet enige med alle de andre ministre om. Jo, øvelsen består i at finde ud af, hvordan man kan reducere fire gange fire, dvs. 16 sagligt begrundede hinkerude-felter til to. For eller imod.

Det kan naturligvis ikke lade sig gøre på nogen intellektuelt forsvarlig vis, ja, det lader sig ikke engang forklæde som fornuft. Så derfor må vi hver gang finde på noget helt andet. Vi opfinder en helt anden diskussion, og den skulle antropologer føle sig hjemme i.

$\mathrm{Vi}$ vender tilbage til de gode gamle dikotomier mellem varme og kulde, inde og ude. Ude er koldt, hjemme er inde og varmt. Europa er ude, hvor de kolde, følelsesløse hjerner diskuterer alt muligt fremmedgørende, mens Danmark er inde, hvor de varme hjerters tanketomme regime giver anledning til den hyggeligste hjemlighed. Holger stemmer med hjertet, og de sølle tilhængere må se sig reduceret til hjerteløse regnemaskiner. Man- 
ge, som scorer nej i færre end fire af de 16 felter, kan se sig reducerede til groteske Hinkelinker, som prøver at hoppe hjem til landsbyen på deres ene nej-ben sammen med Holger og Pia, mens visse, der ikke har fire ja'er, må se sig som Haltefanden på vej til, i selskab med Uffe, at sælge endnu en kristensjæl til den onde i Bruxelles.

Hjertet står over for hjernen. Dette er en dikotomi, og derfor kan den meningsfuldt sendes til folkeafstemning. Man kan udmærket godt stemme ja eller nej til spørgsmålet om kulde eller varme. At det ikke har meget at gøre med de spørgsmål, som faktisk afgøres ved folkeafstemningerne om traktaterne, er ikke så væsentligt. Det vigtige er, at emnet egner sig til en digital afgørelse - i modsætning til de spørgsmål, som i realiteten bliver afgjort ved afstemningerne.

Antropologer har med megen entusiasme studeret varme-kulde-systemer hos andre folkeslag. Det kunne man vel også gøre i dette tilfælde, hvorfor ikke? Jo, det, vi studerer, er næsten altid de store, indviklede systemer, der kommer i spil, når varmt og koldt skal artikulere sig med hinanden i daglig praksis. Det kan man skrive tykke, herligt komplicerede bøger om, fulde af overraskelser og finurligheder. Men i EU-debatten er det lige omvendt. Der har vi tværtimod årti efter årti haft lejlighed til at iagttage, hvordan komplicerede systemer reduceres til enkle dikotomier. Det svarer til at se klodens mangfoldighed glide langsomt ned ad entropiens skrænt, og dét er simpelthen - kedeligt. Der er ikke andre ord for det. Og da navnlig ikke i det lange løb.

Anne Knudsen 
